\title{
Imagination Made Real: Paul between Political Realism and Eschatological Hope
}

\section{1 \\ Paul and His Readers}

"The invisible Kingdom of God, the realm of Messiah, ran into an undeniable conflict with the idea of unconditional obedience to Imperial authority." With these words Leopold von Ranke, the "father" of modern history, constructed the political problem of early Christianity. In the third volume of his massive world history, Ranke extols Paul as the person who successfully united the new faith with the Empire. ${ }^{1}$ It is true that Romans $13: 1-7$ is a loyal paean to the divinely instituted state. In these verses, Paul claims that God has instituted all governing authorities and that every person must be subject to them. Ranke's progressive contemporaries were less convinced of the blessings to unite Christian convictions and the state. Karl Marx saw religion as the reflection of a human self "in the fantastic reality of heaven," although people should seek "true reality." It is an oppressive society, the state that creates the need of a religious fantasy. "This state and this society produce religion," Marx stated in an introduction written in 1844 for his earlier treatise $A$ Contribution to the Critique of Hegel's Philosophy of Right. ${ }^{2}$ He famously called religion an opiate that eased the distress of real conditions.

Religious distress is at the same time the expression of real distress and also the protest against real distress. Religion is the sigh of the oppressed creature, the heart of a heartless world, just as it is the spirit of spiritless conditions. It is the opium of the people. To abolish religion as the illusory happiness of the people is to demand their real happiness. The demand to give up illusions about the existing state of affairs is the demand to give up a state of affairs which needs illusions. The criticism of religion is therefore in embryo the criticism of the vale of tears, the halo of which is religion.... Thus the criticism of heaven turns into the criticism of the

1 Ranke 1883, 182, 184; my translation.

2 Marx 1975, 175. 
earth, the criticism of religion into the criticism of law and the criticism of theology into the criticism of politics. ${ }^{3}$

The union of faith and empire is just to let the oppressive society get on. Developing the Marxist criticism of religion, Mikhail Bakunin, one of the founders of anarchist theory, required the end of religion, as it is the root of all exercises of power. Whoever invokes the divine revelation enslaves the other, he promulgated in God and State, published posthumously in 1882:

These, once recognized as the representatives of divinity on earth, as the holy instructors of humanity, chosen by God himself to direct it in the path of salvation, necessarily exercise absolute power. All men owe them passive and unlimited obedience; for against the divine reason there is no human reason, and against the justice of God no terrestrial justice holds. Slaves of God, men must also be slaves of Church and State, in so far as the State is consecrated by the Church. This truth Christianity, better than all other religions that exist or have existed, understood.... The idea of God implies the abdication of human reason and justice; it is the most decisive negation of human liberty, and necessarily ends in the enslavement of mankind, both in theory and practice.... If God is, man is a slave. ${ }^{4}$

One may marshal Romans 13 to prove Bakunin's point. Paul seems to bring a divine consecration for earthly rulers - and this is celebrated by conservatives like Ranke. The conservatives were, however, heavily challenged by Marxists, anarchists, and other revolutionary forces of the time. In the 2oth century, the social criticism of religion really took wing in the communist societies. According to Vladimir Lenin, religion is an instrument used to maintain capitalist society, where the "free" workers receive just minimum subsistence to uphold this capitalist slavery. ${ }^{5}$ In his Socialism and Religion (1905), Lenin proclaimed that religion is like an opiate or booze.

Religion is one of the forms of spiritual oppression which everywhere weighs down heavily upon the masses of the people, overburdened by their perpetual work for others, by want and isolation.... Those who toil and live in want all their lives are taught by religion to be submissive and patient while here on earth, and to take comfort in the hope of a heavenly

3 Marx 1975, 175-176; original emphases.

4 Bakunin 1907, 24-25.

5 Lenin 1978, 83 . 
reward. But those who live by the labour of others are taught by religion to practise charity while on earth, thus offering them a very cheap way of justifying their entire existence as exploiters and selling them at a moderate price tickets to well-being in heaven. Religion is opium for the people. Religion is a sort of spiritual booze, in which the slaves of capital drown their human image, their demand for a life more or less worthy of man. ${ }^{6}$

The metaphors of opium and booze do not simply label religion as a tool to dull the senses of the oppressed in order that they remain in their place. They also ease the pains of those in an oppressive society, and this seems to contain elements of medicine. ${ }^{7}$ Interestingly enough, Lenin went even further, in passing acknowledging the revolutionary spirit in early Christianity, which was "forgotten" with Constantine's turn in the fourth century: "Christians, after their religion had been given the status of state religion, 'forgot' the 'naïveté' of primitive Christianity with its democratic revolutionary spirit." ${ }^{8}$ This comes close to Ranke who, however, dated the extinction of the revolutionary enthusiasm back to Paul and Romans 13. Interestingly, both conservatives like Ranke and progressives like Lenin acknowledged revolutionary and loyalist sides in Christianity. They differed only in their sympathy for the opposite sides. Ranke is right in invoking Romans 13. Paul really contributed to the maintaining of state authorities, as shown by the history of influence. Still, one may ask whether this is the whole truth of the early Christians or even of Paul. I claim that the revolutionary spirit is hidden in what Marx and his followers arrogantly labeled as a fantasy and what I think of in positive terms as the active imagination. Paul was a kind of political realist, but he does not exemplify Bakunin's mechanism between religion and the state. My claim is that Paul provides little support to Marx's and Lenin's view that eschatology was only a narcotic fantasy meant to dull the senses of the oppressed, in order to keep them passively in their existential conditions. Instead, eschatology is a force for change in society, that is, by turning what is actively imagined into something true and real.

I start this chapter by positioning Paul among his fellow Christians. Paul is quite open toward the Empire-at least in comparison with John the Seer, who seems to be openly hostile toward it. Romans 13 is the antithesis to John's

6 Lenin 1978, 83-84. In his State and Revolution (1918), Lenin castigated those German Social Democrats, who renounce "the party struggle against the opium of religion which stupefies the people" (Lenin 1974, 455).

7 For the dual implication of these metaphors, see Boer 2013a, 9-30.

8 Lenin 1974, 425. The idea is older and one encounters it, for example, in Friedrich Engels (1894-1895). 
eschatology. Its call for unlimited obedience has always posed a problem for interpreters. I go through the exegetical and other efforts to find a principle that relativizes absolute obedience, but I keep them factitious. Next, I show how Paul's thought belonged to the philosophy of the stronger in ancient tradition, as well as the positive outcome that Paul expected of it. Last, I demonstrate how Paul's eschatology provides a detour regarding social change. This change does not come in terms of the revolutionary force expected by Marx and Bakunin, and implemented by Lenin; this (Bolshevik) revolutionary force turned out to be just another variant of the old pattern of oppressive violence. The imagined dream comes true by peacefully eroding the legitimation of human hierarchies.

\subsection{Paul's Openness toward Roman Society}

The kingdom of God is a multi-dimensional concept, the use of which in the Bible is impossible to systematize into one consistent whole. It is-like eschatological hopes in general-thought to be realized in the present age or in the future, in heaven or on earth, spiritually or materially, individually or collectively. Its conflicting visions of catastrophe and new hope have invited countless interpretations. ${ }^{9}$ While Paul seems to have a tendency of seeing eschatology as something that will be realized spiritually in heaven and individually in the future, the other dimensions are still visible. ${ }^{10}$ Revolutionary or even anarchic dynamite can be felt, for example, in the claim that Christ will give the kingdom to God after destroying "every ruler and every authority and power" (1 Cor 15:24). What is worse, this conflict was even at the heart of Paul's faith: he liked to know nothing except "Jesus Christ, him crucified," and it was "the rulers of this age" who "crucified the Lord of glory" (1 Cor 2:2, 8)." There is no need to pursue a hidden criticism of Roman power, which is so popular in the anti-imperial reading but highly difficult to ascertain..$^{2}$ Paul's actual words are enough to prove his critical stance, like Anders Klostergaard

For an overview, see Räisänen 2010, 79-113. Räisänen makes some references to the later adaptations.

10 Räisänen 2010, 98-102.

11 It is not absolutely clear that Paul is speaking here of mundane authorities; one can also see them as celestial angelic or demonic powers. Schrage (2001, 173-174; 2008, 253254 ) sees a double meaning in these verses. Jewett $\left(2007,55^{2}\right)$ sees Rom 8:32 as a possible critical note on mundane authorities, but he admits that this reading is not very well grounded. I prefer to see only celestial powers in this context.

12 Heilig (2015) provides an illustrative reflection of the claims regarding the hidden criticism. 
Petersen states: "Definitely, any Roman ruler whom we imagine to have had access to the text would hardly have been satisfied with what he found."13

These words of Paul are not what Bakunin might expect, however. For Bakunin, at the heart of all representatives of religion is "something cruel and sanguinary," a hierarchy that sacrifices humanity. ${ }^{14}$ However, Bakunin might be defended by the fact that, as far as we know, the anarchic and revolutionary elements of early Christianity never led to real deeds of rebellion. There is no evidence of Christians participating in the Jewish revolutionary movements. ${ }^{15}$ During the Jewish War (c. 6o-7Os CE), Christians fled from the war zone (Eusebius, Hist. Eccl. 3.5.3; cf. Matt 24:15-16; Mark 13:14; Luke 21:20-21). ${ }^{16}$ Still, there really was a potential for conflict that was, from time to time, realized in persecutions. Possibly the most famous case is the description of the Beast in the Book of Revelation: "it was allowed to make war on the saints and to conquer them" (Rev. 13:7). Although the Beast is a shadowy figure, it was identified already in antiquity with the Roman Emperors who forced Christians to make offerings in the imperial cult. ${ }^{17}$ Another example is the (even contemporary) idiom of carrying one's cross. The idiom is inherited from the idea of imitatio Christi, the central motif of Christian ethics, which emphasizes the readiness to suffer. In its scriptural roots (Matt 16:24; 10:38; Mark 8:34; Luke 9:23; 14:27), it was not merely an exaggerated figure of speech.

In the pagan sources, the historian Tacitus describes the early persecution in Rome during the 6os CE. Although he maintains that Emperor Nero falsely scapegoated Christians for the burning of the city, he adds that the Christians got what they deserved for their hatred for humankind (Tacitus, Ann. 15.44). Suetonius lists the persecution among Nero's good deeds (Nero 16). As governor of Asia Minor, Pliny the Younger reports on his measures against the local Christians (Ep. 10.96). John Granger Cook takes these texts as evidence of the

13 Klostergaard Petersen 2015, 117.

14 Bakunin 1907, 26.

15 Among Jesus' disciples, Simon the Zealot (Luke 6:15) is possibly the closest candidate for a rebel, but we do not know if his nickname really refers to the rebellious Jewish movement or if he was rather just zealous in other meanings of the word. Note, for example, that Paul refers to his pre-Christian identity as "a Zealot of the traditions of my ancestors" (Gal 1:14; revised version of the NRSv), which meant persecuting the Christians, not fighting the Romans.

16 In addition to the Jewish War in Palestine, there was the so-called Bar Kokhba Revolt in the $130 \mathrm{OSE}$. In diaspora, there was a vast Jewish uprising in 115-117 CE. See, e.g., Räisänen 2010, 28.

17 Actually, there are two beasts in Rev. 13. The first one is an Emperor, probably Nero redivivus (i.e., the arisen Nero; in depth on this, see Aune 1998, 713-78o). On the interpretations of the Beast in the Early Church, see Ancient Christian Commentary on Scripture, 196-203. 
Roman disgust and shock at the phenomenon of Christianity. ${ }^{18}$ Yet, one should not exaggerate the persecutions. Before the mid-third century CE they were just sporadic and local, incited by the neighborhood rather than by officials, who were often somewhat reluctant in their punitive measures after Christians were denounced to them. John the Seer, the author of the Book of Revelation, seems to exaggerate some real experiences in its apocalyptic worldview, which provided an expectation of the eschatological war against the saints (cf. Dan $7: 21) .{ }^{19}$ This expectation was rooted in a continuous feeling of threat. Christians bore a social stigma that increased the risk of negative encounters, although this stigma did not always lead to violent hostilities. ${ }^{20}$

The conflict between Christians and the society in which they lived was not the only truth. As I showed earlier, there were philosophers like Epictetus (a contemporary of Tacitus, Suetonius, and Pliny), who highlighted the Christians as moral examples, despite his lack of any deeper interest in Christianity (Disc. 2.9.19-21; 4.7.6). At the same time, the evangelist Luke thought that a Roman soldier could be a Christian (Acts 10). Only a century later, a Christian soldier was no exception, despite objections made by early Christian intellectuals like Tertullian (see, e.g., his treatise De corona). ${ }^{21}$ Actually, John the Seer was a Christian hardliner who drew an extremely clear line between "us" and "them," and blamed his Christian companions for their readiness to adjust themselves to this world and society. The target of his criticism was, among other things, having too liberal of an attitude toward food sacrificed to idols ( $\operatorname{Rev} 2: 14,20)$. The attitude under scrutiny was that of Paul, who counted "idol food" among the adiaphora, considering that one should merely give up eating "idol food" lest it insult persons like John, who still falsely held that such things make a difference $(1$ Cor $8 ; 10){ }^{22}$

Paul's openness toward pagan society is also reflected in his attitude toward the Roman Empire. Heikki Räisänen states: "Unlike the seer of Revelation,

18 Cook 2010, 2.

19 Räisänen 2010, 288-295.

20 For example, expulsion orders were often more symbolic than real acts. These orders, like other proclamations, confirmed social order (van der Lans 2015). This does not mean that proclamations were without effect. Paul Holloway $(2009,36)$ notes that "scholars of early Christianity make a serious mistake when they focus on the 'local and sporadic' nature of early Christian persecution - as if tallying actual deaths allows one to somehow quantify the lived experience of lethal prejudice - and ignore this much more fundamental and abiding problem." Possibly Candida Moss goes too far in diminishing the extent of persecutions in her The Myth of Persecution (2013).

21 See Chapter 4.

22 Paul's thought is somewhat ambiguous in 1 Cor 8 and 10, but the main line is clearly liberal toward eating "idol food." On this issue in early Christianity, see Räisänen 2010, 285-288. 
Paul, a middle-class cosmopolitan of sorts, apparently does not experience Roman rule as something from which he specifically needs to be redeemed."23 Thus, there was undeniably a clear potential for conflict with the Empire, but it did not necessarily need to be an actual one. Despite the occasional critical comments of earthly rulers, Paul was far from a political dissident. The only passage where he intentionally discusses the relationship with the state authority proves the opposite. In Romans 13:1-7, he explicates the relationship toward the Empire in a way that has steered attitudes since then in the Western world. Paul's influence is visible already in the New Testament itself. Sayings in 1 Timothy 2:1-2, Titus 3:1, and 1 Peter 2:13-14 are clearly dependent on Romans 13:1-7. In later documents, Paul's words repeated frequently until today. ${ }^{24}$ This fact supports Ranke claim that Paul's Epistle to the Romans is "a monument of the most important class." According to him, Paul made room for the state and the Emperor within the new faith. He ascribed the existence of all, even the Emperor, to the monotheistic God. "Everything is united in Paul's thinking," Ranke extols, adding: "This is the sum of his apostleship."25

\subsection{Avoiding Offense: Exegetical Attempts}

Not everyone agrees with Ranke's praise for Paul and Romans 13. Some readers of Paul are offended. Neil Elliott, one of the main representatives of the socalled anti-imperial reading of Paul, feels uncomfortable. ${ }^{26} \mathrm{He}$ makes a general claim that Paul's thinking is "ideological intifada," a "call for resistance," and "revolutionary." By contrast, the exhortation to subordinate all to the governing authorities "threatens to capsize every Christian liberative project," which Elliott laments, referring to Romans $13: 1-7$ as a theological offense. ${ }^{27}$ In the modern Western world, Elliott's lamentations have been more typical than Rankean praises. These lamentations vaguely reflect the 19th-century anarchist and revolutionary tradition. Yet, this stance regarding Paul has a point that is difficult to accept. Paul straightforward requires obedience to any authorities that happen to be in power, because that authority is instituted by God to

23 Räisänen 2010, 101.

241 Tim and Tit are usually seen as later productions of the "Pauline school" in a similar manner as some of Plato's epistles. For the dependence between 1 Pet and Rom, see, e.g., Elliott 2000, 38. On the history of influence, see, e.g., Wilckens 2008, $44 \mathrm{ff}$.

25 Ranke 1883, 182, 184; my translation.

26 In fact, Elliott has grown calmer and distanced himself from his earlier readings of Rom. 13 (Elliott 2011, 48). For an overview on the anti-imperial reading of Rom. 13:1-7, see Krauter 2009, 28-32.

27 Elliott 1995, 217, 230. Blumenfeld $(2003,396)$ thinks that Elliott's work is provocative and "suited to a discourse on oppression and liberation, a modern political theme." 
promote good and resist evil. Although the politics of recognizing earthly rulers was not without predecessors in Judaism, ${ }^{28}$ there is one atypical element in Paul that threatens to ruin any critical attitude: unlimited theological justification for the state. This point has always raised questions. The reading strategies among both biblical scholars and the more general audience demonstrate the attempts to avoid this offense. ${ }^{29}$

One of the most frequently proposed limitations is found in the fact that, according to Paul, the authorities promote good. This is thought to mean that only those authorities promoting good should be obeyed. But this is not what Paul says. He claims simply that the authorities promote good, without exception. A critical reader must surely marvel at this, but this is what Paul says-if he speaks of earthly authorities at all. In fact, this is another attempt to ease the offense. Irenaeus already knows the interpretation that the Greek words for authority ( $\left.\xi^{\xi} \xi o v \sigma i \alpha, \grave{\alpha} p X 0 v \tau \varepsilon \varsigma\right)$ do not denote civil authorities but angelic powers (Haer. 5.24.1). Thus, Paul would not be speaking of obedience to the state at all, or he is referring only to obedience to the angelic powers behind it. In modern times this interpretation is mainly associated with Oscar Cullmann, who promoted it in his Der Staat im Neuen Testament. ${ }^{30}$ Actually, the interpretation had its lure already among early critics of the Nazis; for example, Karl Barth promoted it in the 193os. Gerhard Kittel, a committed Nazi himself, grap-

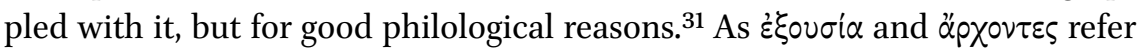
generally to power and authority, there should be some implication around the spiritual character of those powers. Paul does not give any hint of that. To the contrary, the context requires political character, as Irenaeus already noted, referring to Romans 13:6: "Now, that he spake these words, not in regard to angelical powers, nor of invisible rulers - as some venture to expound the passage - but of those of actual human authorities, [he shows when] he says, 'For this cause pay ye tribute also: for they are God's ministers, doing service for this very thing'" (Haer. 5.24.1; trans. ANF 1.552). In recent decades, the spiritualizing interpretation has been unanimously dismissed. ${ }^{32}$

Interpreters have also searched for the limiting principle in the textual context of the epistle. In the beginning of his paraenetic part, Paul admonishes Christians not to "be conformed to this world" (Rom 12:2), which some

\footnotetext{
28 Riekkinen 1980, 53-6o.

29 Boer $(2013,182-183)$ seems to use quite similar examples to those I mention. See also Harrison 2011, 271-277.

$30 \quad$ Cullmann 1959.

31 Kittel 1939, 48-54. On Kittel's Nazism, see, e.g., Ericksen 1977.

32 Krauter 2009, 11-12. This is true of another exceptional interpretation, namely, that the words refer to synagogue rulers (Harrison 2011, 270).
} 
scholars interpret as drawing a line vis-à-vis obedience. ${ }^{33}$ This is a very ambiguous passage, however. One can easily reconcile it with the admonition to obey the authorities. Conforming to this world is against God's will. If God's will entails obedience toward authorities, conforming to this world is expressed in worldly resistance. The reference to "this world" is too hazy to provide an interpretative exit from the obedience. Another exit is sought in Paul's eschatology. Shortly after his words on authorities, Paul reminds the readers of the imminent eschatological change (Rom 13:11-14). Can it relativize the state authorities and obedience to them? Is it more important to "put on the Lord Jesus Christ" than to obey the authorities? Possibly yes, but does this lead to any resistance? At least in 1 Corinthians, the imminent end seems to lead to a conservative stance: everyone should remain in his or her social position without seeking to change it (1 Cor 7 ). It is meaningless to search for a change in a situation that is soon disappearing. ${ }^{34}$ In the textual context, there is nothing mitigating the admonition to obey the authorities. Biblical scholars have also sought to contextualize Paul's words in relation to the political situation of his time. Scholars have supposed that Paul recommended loyalty because of this or that political disturbance, be it tax uprisings, the problems between Jews and Romans (cf. Suetonius, Claudius 25.4; Acts 18:2), or strife between the Jews and the Christians. Thus, Paul's admonition would be situational rather than general..$^{35}$ The problem is that Paul hints at no situational factors.

Some scholars grant that the passage admonishes unlimited loyalty toward the state authorities - only to explain that Paul never could have said or meant it. Some claim that the passage is not originally a part of the epistle but an early

33 See, e.g., Jewett 2007, 732.

34 Huttunen 2009, $26-36$. It is also proposed that Paul stoically counted the authorities among the adiaphora (Engberg-Pedersen 20o6). This, however, would not necessarily lead to resistance any more than the idea of an imminent end. Moreover, Paul speaks of fear

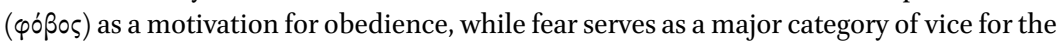
Stoics. For the Stoic theory of emotions, see, e.g., Brennan 1998. For the contrast between Paul's thought and that of the Stoic Epictetus, see Huttunen 20o9, 96. Ironically, Epictetus praises Christians for their habit of not yielding to fear before tyrants (Discourses 4.7.6; see Chapter 2)!

35 See, e.g., Friedrich, Pöhlmann, and Stuhlmacher 1976; Harrington and Keenan 2010, 171. Krauter (2009, 12-15) and Harrison (2011, 271-272) have helpfully presented these situational explanations. Georgi $(1991,102)$ provides a variant of the situational interpretation. He points out that Paul never mentions the princeps and, thus, refers to the republican tradition urging decentralization and undermining the ideology that supports majesty. Paul did not mention the emperor, unlike 1 Peter, but his words are too general to promote republican ideas. It is more probable that Paul refers to the general hierarchy between the rulers and the ruled - be that hierarchy republican or imperial. 
addition to the text. ${ }^{36}$ No manuscript evidence backs up this claim, however, and the scholarly majority has rejected this theory. ${ }^{37}$ In the so-called antiimperial reading of Paul, it has been claimed that Paul's words constitute such exaggerated praise for the authorities that a wise reader cannot miss the irony. Paul tried to undermine and subvert the social structures. ${ }^{38}$ Unfortunately, the reading is anything but obvious. I am not conscious of any ironic reading of Romans 13 before the "anti-imperialists." Robert Jewett explains that Paul ascribes the power behind the authorities to the God of Israel, not to the Roman gods. He claims that this is subversive in terms of political theology. ${ }^{39}$ But this is hardly true. Actually, there was indeed a Jewish imperial theology. It is a standard view in the Hebrew Bible that power comes from God; for example, one reads: "He changes times and seasons, deposes kings and sets up kings" (Dan 2:21). Josephus allows King Agrippa to express the same idea concerning the Roman Empire: "Without God's aid, so vast an empire could never have been built up" (Josephus, Bell. 2.391; trans. Thackeray, LCL). The cultic expression of this imperial theology constituted the daily offerings on behalf of Romans and the Emperor (Josephus, Bell. 2.197). The end of these sacrifices erupted in revolt, as Josephus states:

Eleazar, son of Ananias the high-priest, a very daring youth, then holding the position of captain, persuaded those who officiated in the Temple services to accept no gift or sacrifice from a foreigner. This action laid the foundation of the war with the Romans; for the sacrifices offered on behalf of that nation and the emperor were in consequence rejected. The chief priests and the notables earnestly besought them not to abandon the customary offering for their rulers, but the priests remained obdurate.

Josephus, Bell. 2.409-410; trans. THACKERAY, LCL

Thus, there was not only a Roman theological legitimation of Empire but also a Jewish one, and it was recognized by Romans as an expression of loyalty. Paul's Romans 13 stays in the tradition of the Jewish imperial theology, albeit not in its cultic form. Paul's theology of political power does not question the rule of the Romans, as Jewett argues, but rather legitimizes it in a way that was acceptable also to them. Paul's words are therefore pro- rather than anti-imperial.

$36 \quad$ See, e.g., Barnikol 1961.

37 Jewett 2007, 789-79o.

38 See, e.g., Carter 2004. For an overview of this reading with critical remarks, see Krauter 2009, 28-32. See also Harrison's (2011, 308-323) reading, which is anti-imperial but finally comes quite close to my reading with its emphasis on Paul's realism (see more below). Jewett 2007, 789-79o. 
I dare to claim that the modern scholarly pains to limit the power of authorities fail. These failed attempts, however, touch on the sore spot felt from the earliest times onward.

\subsection{The Unease of the Christian Tradition}

The reception history of Paul's words has always radiated a certain unease. 1 Tim 2:1-2 is an admonition to pray for the authorities in order to maintain peace for the Christians (cf. 1 Clem 61). Are the authorities not always good, as Paul assumes, in the sense that Christians must pray for peace from the side of the authorities? Traditionally the authority ascribed to the state by Paul is limited by a reference to the clausula Petri: "We must obey God rather than any human authority" (Acts 5:29). ${ }^{40}$ Acts 5:29 is just one variant of Socrates' famous saying, "I shall obey the god rather than you" (Plato, Apol. 29d; trans. Emlyn-Jones and Preddy, LCL), which has a rich history of influence. For example, Epictetus states: "When you come into a presence of some prominent man, remember that Another looks from above on what is taking place, and that you must please Him rather than this man" (Disc. 1.30.1; trans. Oldfather, LCL). Thus, the use of Acts 5:29 to limit the authority of earthly rulers merely continued the ancient tradition in Christian form. Tertullian requires that obedience be limited to the area outside of the spiritual sphere. If rulers demand authority in divine issues, a Christian should be ready for martyrdom (Scorp. 14).41 The same trend is visible in later times. Martin Luther, who also refers to Acts 5:29 (among other biblical verses), limits state authority to earthly issues and requires freedom of religion, which can be manifest, for example, in the denial to hand over religious books. ${ }^{42}$ Actually, this is how Ranke understood Paul: a Christian should have freedom of religion, while it is the job of state to punish wrongdoers. ${ }^{43}$

In the Western sphere, law later became the main source for limits on the power of authorities, mainly monarchs. This also had an effect on the interpretation of Romans 13, and therefore it is worth looking at the background of this legal thinking. Francis Fukuyama points out that the rule of law has religious origins and that this principle is known around the world: law is binding because it is higher than those holding political power. In Western

40 The NRSV gives an alternative translation: "than men." This is actually closer to the Greek (anthrōpois). The translation "authority" is in itself possible evidence for the fact that this verse is often read in parallel with the authorities in Romans 13. For the use of Acts 5:29 in the interpretation of Rom 13, see Wilckens 2008, 45 .

41 See translation in Ante-Nicene Fathers 3.

42 Von weltlicher Oberkeit, $1523=$ WA 11, 265-271.

43 Ranke $1883,184$. 
Europe, the rule of law developed further for institutional reasons; as a religious authority the Catholic Church became independent of the monarchs and was itself rooted in the idea of legal rule. According to Fukuyama, Western Europe clearly differs from other societies: "The result was that few European monarchs ever acquired the concentrated powers of the Chinese state, despite aspirations to do so. Only in Russia, where the Eastern Church was always subordinated to the state, did such a regime emerge." ${ }^{44}$ In the Reformation, the nascent Lutheran churches became subordinated to the royalty, but the idea of legality seems to continue the earlier tradition and "resist" absolute monarchy. For example, Swedish bishop Olaus Petri's (1493/1497-1552) rules for judges (still printed in the Swedish and the Finnish statute books) express this legal tradition: "Because a judge is commanded by God to judge right, he ought to labour with all his might and craft to know the law." This divine law is not necessarily identified with positive law. Rather, the positive law should be viewed in light of divine justice: "What is not just and fair cannot be law either."45 This legal tradition strengthened in Europe from the 18th century onward. I will discuss two important moderators and their effect on the interpretation of Romans 13 .

First, Immanuel Kant's political theories strongly promoted the idea of political authorities subordinated to the law. In his Science of Right (Metaphysik der Sitten, 1797), Kant emphasized the duty to obey the authorities, coined by the Lutheran neologism Obrigkeit for Romans 13 and certain other biblical passages. ${ }^{46}$ Romans 13 is explicitly paraphrased and called a categorical imperative, while Kant admits its objectionable character:

Now, it is asserted that obedience must be given to whoever is in possession of the supreme authoritative and legislative power over a people; and this must be done so unconditionally by right, that it would even be penal to inquire publicly into the title of a power thus held, with the view of calling it in doubt, or opposing it in consequence of its being found defective. Accordingly it is maintained, that 'Obey the authority which has power over you' (in everything which is not opposed to morality), [Gehorchet der Obrigkeit (in allem, was nicht dem inneren Moralischen widerstreitet), die Gewalt über euch hat] is a Categorical Imperative. This

\footnotetext{
44 Fukuyama 2014, 12.

45 An introduction and an English translation of Olaus Petri's Rules for Judges, see Tontti 2000.

46 For more on the neologism in the Lutheran tradition, see Huttunen 2019.
} 
is the objectionable proposition [der anstößige Satz] which is called into question. ${ }^{47}$

Kant straightforwardly nullifies the duty of obedience, if Obrigkeit opposes morality. This, however, is not his main point. Instead, he searches for a general justification for obedience-and finds it in the idea of a legal constitution (Staatsverfassung). A people is "united by laws under a sovereign power (durch Gesetze unter einer Obrigkeit vereinigt)." Therefore, people cannot simultaneously be entitled to oppose "the Constitution, however defective it may be," since it "would result in a supreme will that would destroy itself." Any defects in the constitution should be gradually removed by reforms. ${ }^{48}$ Kant reduces Obrigkeit to laws and especially to the constitution. Instead of obedience toward certain persons (authorities), Kant sees Obrigkeit as a system of government steered by a legal constitution, which can be reformed if needed.

Second, Georg Wilhelm Friedrich Hegel (1770-1831) became another influential moderator. In his Lectures on the Philosophy of Religion, he (according to the editors of this posthumous publication) made a connection between religion and government in a way that Bakunin did later as well. Hegel, contrary to Bakunin however, held this connection as good: "A nation which has a false or bad conception of God, has also a bad State, bad government, bad laws." Clearly referring to Romans 13 , Hegel says that this connection finds its vernacular expression "in the tracing of laws, authority [Obrigkeit], and the constitution of the State to a divine origin." Hegel clarifies: "It may be taken as meaning that man obeys God in the act of conforming to the laws, to the ruling authority [indem man den Gesetzen und der Obrigkeit folgt], to the powers which hold the State together." ${ }^{\prime 9}$ Hegel points out that the duty of obedience should not lead to the incorrect view that people are obliged "to obey the laws whatever they may happen to be. In this way the act of governing and the giving of laws are abandoned to the caprice of the governing power." Hegel sees that the problem is most difficult in Protestant countries, where the "unity of religion and the State actually exists." He explicitly refers to the system of state churches and gives special attention to England, where "the ruler was responsible for his actions to God only" during the last kings of the House of Stuart. This also assumes that the ruler knows what is good in the state so that he unites

47 Metaphysik der Sitten Rechtslehre I, Beschlu $\beta=\operatorname{Kant}(1999,371)$; trans. Hastie (p. 256).

48 Metaphysik der Sitten Rechtslehre I, Beschlu $\beta=$ Kant (1999, 371-372); trans. Hastie (pp. 256-257).

49 Vorlesungen über die Philosophie der Religion I: 237-238; trans. Speirs and Burdon Sanderson (pp. 247-248). 
God's will and the state laws. Hence, "he is an immediate revelation of God." Hegel, however, claims that this runs against the Protestant conviction, which holds that there is no distinction between priests and laymen, as priests are not the sole possessors of divine truth. Hegel concludes: "But even supposing that the general principle at least has been established that laws exist through an act of the divine will, still there is another aspect of the matter which is just as important, namely, that we should have a rational knowledge of this divine will, and such knowledge is not anything particular or special, but belongs to all."50 Thus, Hegel limits the duty of obedience-a feature so common in the reception history of Romans 13. Ultimately, he left it up to the individual to consider whom one obeys and whom one does not. This is something, at least in my own Finnish tradition, that is still visible in the idea of a specifically legal authority. It blocks out obedience to just any kind of authority. ${ }^{51}$

The reception history among both biblical scholars and other readers shows that the limiting principle-be it clausula Petri, law, or something else-has been brought outside of the passage itself. This betrays the fact that to find a limiting principle in the passage fails. Those rare persons who were happy with the idea of unlimited power could cite Paul's words without further commentaries. Thomas Hobbes, who championed the unlimited power of the sovereign over society, cites Romans 13:1-6 in order to show that there is no excuse for disobedience to the "civill authority," not even a faith-based one. ${ }^{52}$ Hobbes understood correctly, as Paul does not place any limits on the authorities in Romans 13. He thinks that their limitless power promotes the good, in any case. It is our task to make sense of this and ask, how could Paul claim such a thing? The answer comes less from theology than from ancient social practice. Scholars and other readers of Romans 13:1-7 have always noted the theological side: the authorities are instituted by God. But what makes God's institution socially visible and what consequences does it have in the moral sphere?

50 Vorlesungen über die Philosophie der Religion I: 238-239; trans. Speirs and Burdon Sanderson (pp. 248-249).

51 Johann Vilhelm Snellman (1806-1881), a very influential philosopher in Finland, maintained that obedience to authority should be developed with an understanding of the rationality of the national law. Pure obedience to authority would mean obedience to any kind of irrational statute or random ruler (Läran om staten $18=$ Samlade arbeten III, 341). Thanks to general conscription, most Finnish men have given an oath where they have sworn loyalty to the legal authority ("laillinen esivalta" "laglig överhöghet"), the background of which is firmly rooted in the political situation at the beginning of the 2oth century (Huttunen 2019). 


\section{Paul's Realism and Imagination}

\subsection{Paul's Political Realism and the Law of the Stronger}

Paul's famous words in Romans 13 are usually read as a moral exhortation to subordinate oneself to the civil authorities. True, this is their character. Paul warns the readers about any rebellion, as it will lead to disaster: those who resist authorities will incur judgment. However, the imperative of the third

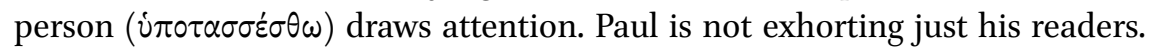
Rather, he expresses a general rule concerning "every soul” ( $\pi \hat{\alpha} \sigma \alpha \psi \nu \times \eta ́)$.

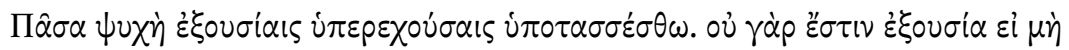

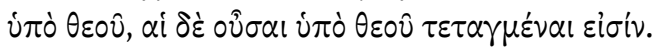

Let every person be subject to the governing authorities; for there is no authority except from God, and those authorities that exist have been instituted by God.

Rom. 13:1

Paul's choice of words recalls the creation story where God creates human beings and lets them govern animals, which are also called "all soul/life of the

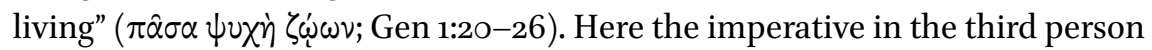
$(\dot{\alpha} p \chi \varepsilon \dot{\tau} \tau \omega \sigma \nu)$ is used, just like in Paul. However, one should also note the dissimilarity between Paul and Genesis 1. While the latter expresses a hierarchy between humankind and animals, Paul speaks of subjects under the rule of authorities. Only the hierarchical thought and the Hebraism ( $\pi \hat{\alpha} \sigma \alpha \psi v \chi \eta \dot{\eta})$ are similar. Paul's words seem to have presented a stumbling block for some early copyists of his text, as if Paul was laying down rules for all life. No wonder that some manuscripts modestly read: "Be subject to all governing authorities"


readers instead of a universal rule. Scholars, however, have nearly univocally rejected this reading as a secondary one. ${ }^{53}$ Paul may have expressed a universal rule, possessing a divine ring, but likely did not intend to set such a rule. The Septuagint is not the only context of Paul's words on authorities, probably not even the primary one. Besides the biblical tone, Paul's words could also resonate in the minds of his Greco-Roman audience. Outside of its Hebraic

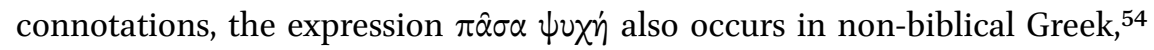

$53 \quad$ Krauter 2009, 171.

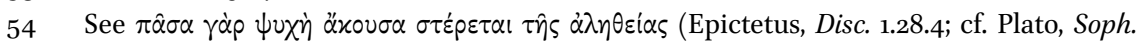
228c). 
and it was fully understandable to any Greek-speaking person. The imperative of the third person occurs in an interesting passage by the Stoic Epictetus.

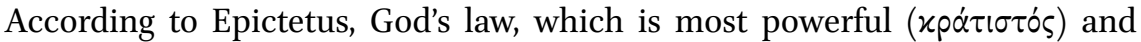
most just, prescribes, "Let the stronger always prevail over the weaker" ( $\tau$ o

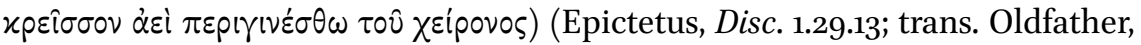
LCL, revised). ${ }^{55}$ The imperative of the third person describes the universality of the rule, as it does in Rom 13.1. ${ }^{56}$

The formal similarities between Paul and Epictetus, however, are less important than the fact that Paul seems to communicate the idea of the law of the stronger. He assumes that one can do nothing but be subject to the authorities, willingly or unwillingly. Paul summarizes the motives to obey in Rom 13:5: "one must be subject ( $\left.\dot{\alpha} \alpha \dot{\gamma} \gamma \eta \eta \dot{\tau} \pi \circ \tau_{\alpha} \sigma \sigma \varepsilon \sigma \theta \alpha l\right)$, not only because of wrath but also because of conscience" (Rom 13.5). Here 'wrath' clearly refers to the sword ( $\mu \alpha \dot{\alpha} \alpha$ < $\rho \alpha)$ the authorities bear, in order to "execute the wrath," or literally as

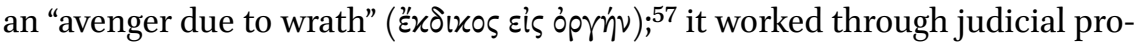
cesses or through direct use of armed power, but Paul does not differentiate between these. ${ }^{58}$ It is all the same to him. One should avoid trying to resist authorities, as it will always lead to disaster. This is the law of the stronger in its rawest form. According to Paul, one is under duress ( $\dot{\alpha} \nu \alpha \dot{\gamma} \gamma \eta)$ caused by wrath and conscience. While wrath refers to violent means, it is more difficult to determine what the duress caused by conscience is. Because conscience refers one way or another to consideration, in this context Paul seemingly refers to an understanding of the divine institution and the rulers' ability to crush the opposition: one should not obey purely out of blind fear, but also because one understands the situation. Paul is not putting forward any ideal of the ruler, unlike philosophers who discussed whether the king should be a living law unto himself in the state, or whether to honor the gods, etc. ${ }^{59}$ Neither is there any trace of the critical attitude toward rulers that is so prominent in the prophetic books of the Hebrew Bible or Deuteronomistic history. ${ }^{60} \mathrm{He}$ is not

55 Epictetus, Disc. 1.29.13; trans. Oldfather, slightly revised.

56 On Epictetus' passage, see Huttunen 2009, 63-65.

57 Here 'sword' does not specifically refer to capital punishment (ius gladii), but to violent power in general (cf. Rom 8:35), which includes capital punishment. While the word हैxठิtxos ('avenger') can also be read in relation to a particular official, the idea of vengeance is present in Rom 12:19.

$5^{8}$ Some scholars of early Christianity are too eager to overemphasize the policing power of local magistrates. This is due to Theodor Mommsen's legacy. Liebs (2005, 204-205) calls for a more precise consideration in readings of the martyr processes.

59 Scholars usually try to discover the background of these philosophical discussions; see, e.g., Bulmenfeld 2003 and Harrison 2011, 277-299.

6o On the philosophers' discussions and the Jewish background, see, e.g., Harrison 2011, 279-308. 
speaking about what the powers should be, but what the powers really are and what their ability to coerce actually constitutes. This is his political realism.

In the Roman sphere, it was the armed forces that pacified the world. In Res Gestae, Emperor Augustus proudly announces that he closed the temple of Janus "when peace had been achieved by victories on land and sea throughout the whole empire of the Roman people" (Res Gestae 13; trans. Cooley). What is romanticized as the Pax Romana indeed has the unacknowledged nature of a violent structure behind all its achievements, as Roland Boer puts it:

The famed Roman roads were not built for the sake of the postal service or for wagons laden with trade; they were for rapid movement of armies, spatial control over the countryside and the movement of statesequestered goods. The infamous Pax Romana (analogous to the Pax Americana of our own day) was actually spattered with the blood of systematic violence, destruction, enforcement and enslavement in order to expand and maintain the Empire. ${ }^{61}$

The legions overpowering the provinces were seen as bringing peace and justice. ${ }^{62}$ The Roman army was not only for warfare. It also attended to the affairs of the internal peace. This police work was not so much aimed at protecting people, however, as attending to the interests of the Empire. ${ }^{63}$ In the case of unrest, "brute force was often expedient and effective, especially in dealing with ill-equipped townsfolk." 64 This is not far from Paul's words concerning the sword, where Roman forces act as "the servant of God to execute wrath on the wrongdoer" (Rom 13:4). One can now see what makes God's institution socially visible. It is the execution of power, not least in its violent form. The public approval for good conduct (Rom 13:3) is just a single exception in the midst of a series of violent and fearful measures.

I claim that Paul's statements are just one part of the Greco-Roman tradition of the law of the stronger, which was deeply rooted in Greek culture. ${ }^{65} \mathrm{In}$ his fable of a hawk and a nightingale, Hesiod let the hawk say: "Stupid he who


is deprived of the victory, and suffers pains in addition to his humiliations."

\footnotetext{
$61 \quad$ Boer 2013, 193-194.

62 On Pax Romana and its ties to such concepts as "freedom" and "safety," see Dmitriev 2o11, 368-377.

63 Campbell 2002, 88; Fuhrmann 2012, 8, 91, 119 .

64 Hubbard 2005, 423.

65 Pace Blumenfeld $(2003,390)$, for whom Paul's concept of power differs from the classical Greek political thinking. In addition to examples of the law of the stronger that I present here, see Räisänen 1992, 81-82.
} 


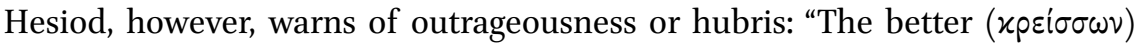
road is the one towards what is just, passing her by on the other side. Justice wins out over Outrageousness $\left(\Delta i x \eta \delta^{\prime}\right.$ ' at the end." Justice is Zeus' law established for human beings, while there is no justice among animals (Op. 210-211, 216-218, 275-278; trans. Most, LCL). Hesiod's warning implies that some people did not see anything wrong with the law of the stronger. Such people are vividly exemplified by Callicles and Thrasymachus, two characters in Plato's dialogues.

Callicles proclaims "that it is right for the stronger to have advantage of the

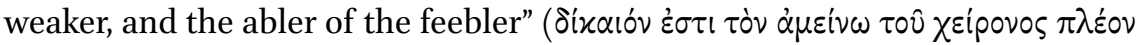

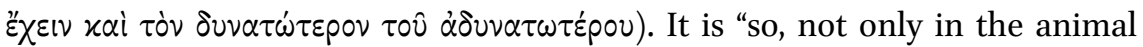
world, but in the states and races, collectively, of men - that right has been decided to consist in the sway and advantage of the stronger over the weaker"

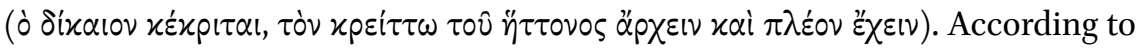
Callicles, this is the law of nature in contrast to the law enacted by humans (Plato, Gorg. 483d-e; trans. Lamb, LCL, revised). Thrasymachus, a cruder variant of Callicles, states his thesis as follows, "I say that justice is nothing other

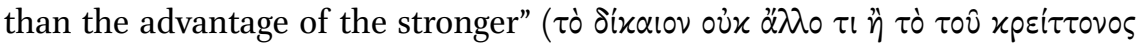
$\sigma \cup \mu \varphi \dot{p} \rho o v)$. Thrasymachus rebukes Socrates for naive illusions. Shepherds and herdsmen consider the good of the flocks because of their master's good or their own. ${ }^{66}$ Nevertheless, Socrates imagines that "the attitude of those who govern our cities (those who really are rulers) toward those who are governed is somehow different from the way one might regard sheep, and that they think of anything else night and day but how to make a profit out of them" (Plato, Resp. 338c, 343b-c; trans. Emlyn-Jones and Preddy, LCL).

Callicles' and Thrasymachus' view of the law of the stronger was not pure speculation, as Plato's contemporary Thucydides attests in the so-called Melian dialogue. The subject of the dialogue is the lot of the city of Melos in the hands of the Athenian army. The Athenians recommend capitulation with the following rationalization: "the powerful ( $\delta \cup v \alpha \tau \dot{\alpha})$ exact what they can, while the weak (oi $\alpha \sigma \theta \varepsilon v \varepsilon i \varsigma$ ) yield what they must." In a good Hesiodian manner, the Melians put their trust in divinity. "We are god-fearing men standing our ground against men who are unjust (ov $\delta$ ixaious)." The Athenians, however, believe that the law of the stronger is accepted by the gods: "For of the gods we hold the belief, and of men we know, that by a necessity of their nature wherever they have

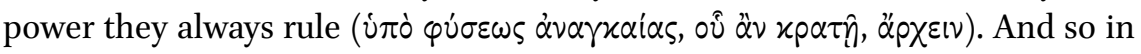
our case since we neither enacted this law nor when it was enacted were the

66 Cf. John 10:11-15, where the shepherd is even ready to die for the sheep. 
first to use it, but found it in existence and expect to leave it in existence for all time, so we make use of it ..." (Thucydides 5.89, 104-105; trans. Smith, LCL).

These classical examples remained well known even in later times. Following the Stoic Posidonius, Seneca supposed that "nature has the habit of subjecting the weaker to the stronger" (potioribus deteriora summittere) (Seneca, Ep. 90.4; trans. Gummere). Josephus also applied the law of the stronger. He tells how he admonished Jews to surrender during the siege of Jerusalem.

Fortune, indeed, had from all quarters passed over to them, and God who went the round of the nations, bringing to each in turn the rod of empire, now rested over Italy. There was, in fact, an established law, as supreme among brutes as among men, 'Yield to the stronger' and 'The mastery

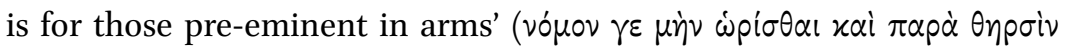

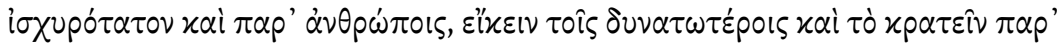
oi $\dot{\alpha} x \mu \eta \dot{\eta} \tau \hat{\omega} \nu$ ö $\pi \lambda \omega \nu$ घival). That was why their forefathers, men who in soul and body, aye and in resources to boot, were by far their superiors, had yielded to the Romans - a thing intolerable to them, had they not known that God was on the Roman side.

Josephus, Bell. 5.367-369; trans. THACKERAY, LCL

Josephus follows the theological tradition-already visible in Thucydides' dialogue as the Athenian standpoint - in which divinity is on the side of the stronger. To make his point even clearer Josephus adds, "listen, that you may learn that you are warring not against the Romans only, but also against God" (Bell. 5.378-379; trans. Thackeray). This is a very close parallel to Paul's words: "whoever resists authority resists what God has appointed" (Rom 13:2). Here we see that both Josephus and Paul embraced the Greco-Roman political theology and adjusted it to their Jewish tradition. One can ask why Paul so strongly turned to the dominant imperial ideology. Would less glorification of the state have been enough? John S. Kloppenborg, referring to postcolonial studies, notes that subaltern groups often adopt a hegemonic discourse so that they can reduce their alterity. For him, Romans 13:1-7 is an example of that. As I have shown, Paul actually embraced a very common and deeply rooted ancient view of society. However, imitation of the hegemonic discourse is only a partial answer. Incomplete imitation presents one as compliant, but it also creates space for identity. ${ }^{67}$ Romans 13:1-7 can be seen as an example of that: at the top of society is the God of Israel, not the Roman gods. As I noted above,

$67 \quad$ Kloppenborg 2014, 181. 
Robert Jewett sees this as subversive in terms of political theology, ${ }^{68}$ but his argument is unsuccessful. I pointed out that Josephus testifies to Jewish imperial theology both on a cultic level (sacrifices in temple) and on a theoretical one. Thus, there was a Jewish tradition recognized by the Romans, and Paul joined in that. This nicely corroborates Kloppenborg's observation of multiple hegemonic discourses. ${ }^{69}$ For Paul, Jewish imperial theology was a means to legitimately avoid the Roman gods. This theological option did not limit the duty of obedience in Romans 13:1-7. The theological differences between the official Roman religion and Jewish monotheism did not create any differences in daily life in the quotidian power structures.

The law of the stronger was well known in the Greco-Roman tradition, including the Jewish part of it. In many of the passages cited, the relationship between power and justice is in focus. Hesiod preferred justice like Plato and Thucydides' Melians; Callicles, Thrasymachus, and the Athenians in the Melian dialogue represent figures who prefer the unscrupulous use of power. Romans 13:1-7 clearly belongs to this discussion on the power play. Paul speaks

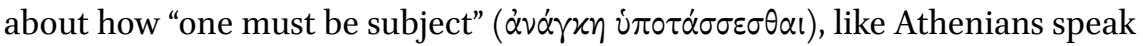

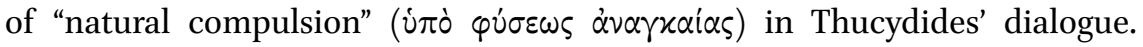
James R. Harrison, who promotes the so-called anti-imperial reading, is ready to admit Paul's realism. Harrison points out that "Paul's heavy emphasis on judiciously 'fearing' the authorities is ... far-sighted acknowledgement of first-century political realities." Even in the end of his analysis on Romans 13, Harrison notes that Paul refused an open resistance as a "tragic miscalculation regarding Rome's determination to suppress all rebellion."70 Next I will show Paul's compliance as one of the ancient strategies to cope with the stronger.

\subsection{Coping Strategies and the Ethics of the Stronger}

Epictetus seems to go in the opposite direction than Paul. He thinks that resistance is both possible and morally acceptable. When speaking of the stronger and the weaker in Disc. 1.29 (cited above), Epictetus is seemingly commenting on Plato's Gorgias. A. A. Long has noted, "Epictetus knew the Gorgias more or less by heart, and he probably included it as one of the main readings for his formal curriculum." ${ }^{71}$ Although Callicles in Gorgias claims the superiority of the stronger, Epictetus answers by taking advantage of the binary meanings in the Greek words $x p \varepsilon i \sigma \sigma \omega \nu$ and $\chi \varepsilon i \rho \omega \nu$, denoting 'stronger' and 'weaker' but

\footnotetext{
68 Jewett 2007, 789-79o.

69 Kloppenborg 2014, 18o-181.

$70 \quad$ Harrison 2011, 313, 323.

71 Long 2002, 70.
} 
also 'better' and 'worse,' which contain moral connotations. ${ }^{72}$ Epictetus states that physical strength and moral strength (i.e., goodness) are two different things. The law of the stronger and the better leads to different conclusions when applied in physical and moral domains:

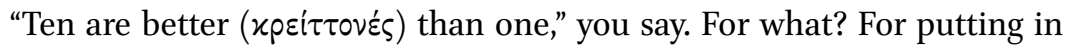
chains, for killing, for dragging away where they will, for taking away a man's property. Ten overcome one, therefore, in the point in which they

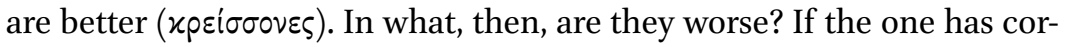
rect judgements, and the ten have not. What then? Can they overcome in this point? How can they? But if we are weighed in the balance, must not the heavier draw down the scales?

Epictetus, Disc. 1.29.14-15; trans. Oldfather, LCL

This differentiation between strength and morality makes it possible to criticize authorities despite their physical supremacy. Socrates is the chief example of this attitude: "The paltry body of Socrates may be carried off and dragged to prison by those who were stronger (i்ò $\tau \hat{\omega} v$ i $\sigma \chi v p o \tau \varepsilon \dot{\varepsilon} \rho \omega \nu$ ) than he" (Epictetus,

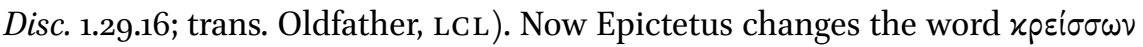

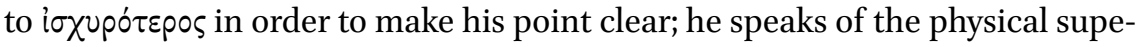
riority. Yet, Socrates was also the prevailing one, as his moral judgements were superior:

But do you prove that one who holds inferior judgements prevails over

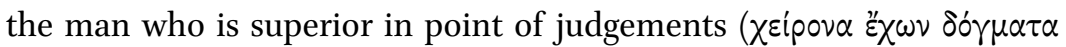

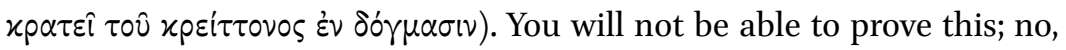
nor even come near proving it. For this is a law of nature and of God: "Let the stronger always prevail over the weaker." Prevail in what? In that in which it is stronger.

Epictetus, Disc. 1.29.19-20; trans. Oldfather, revised ${ }^{73}$

In addition, the differentiation between the stronger and the better makes it possible to differentiate between physical and mental freedom. The person who is physically subjugated can prevail in a moral sense. This opens the possibility for a moral resistance, as, for example, the following passage proves:

72 See Liddell, Scott, and Jones 2011 on $x p \varepsilon i \sigma \sigma \omega \nu$ and $\chi \varepsilon i p \omega \nu$.

73 For a further analysis of Epictetus' text, see Huttunen 2009, 63-65. 
For when the tyrant says to a man, "I will chain your leg," the man who has set a high value on his leg replies, "Nay, have mercy upon me," while the man who has set a high value on his moral purpose replies, "If it seems more profitable to you to do so, chain it." "Do you not care?" "No, I do not care." "I will show you that I am master." "How can you be my master? Zeus has set me free. Or do you really think that he was likely to let his own son be made a slave? You are, however, master of my dead body, take it." "You mean, then, that when you approach me you will not pay attention to me?" "No, I pay attention only to myself. But if you wish me to say that I pay attention to you, too, I tell you that I do so, but only as I pay attention to my pot."

Epictetus, Disc. 1.19.8-10; trans. Oldfather, LCL

A non-Stoic would mistakenly identify his freedom with the freedom of the body. The Stoic, however, is interested in mental freedom. ${ }^{74}$ Epictetus does not hide his bold attitude toward tyrants, who are recurrent figures in his Discourses. ${ }^{75} \mathrm{He}$ also expresses his resistant attitude in words that remind of Romans 13:

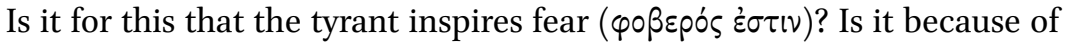
this that his guards seem to have long and sharp swords ( $\tau \dot{\alpha} \varsigma \mu \alpha \chi \alpha i p \alpha \varsigma)$ ? Let others see to that; but I have considered all this, no one has authority ( $\dot{\xi} \xi \circ v \sigma i \alpha \nu$ ) over me. I have been set free by God, I know his commands, no one has power any longer to make a slave of me, I have the right kind of advocate, and the right kind of judges.

Epictetus, Disc. 4.7.16-17; trans. Oldfather, LCL, revised

God's commands, which are equivalent to philosophy, ${ }^{76}$ make it possible to resist authorities. In contrast, Paul claims that those resisting authority $\left(\dot{\xi} \xi \circ v \sigma^{\prime} \alpha\right)$ resist God's ordinance $(\delta 1 \alpha \tau \alpha \gamma \dot{\eta})$. Moreover, the issue of fear is central in Disc. 4.7, as its title "Of the freedom from fear" expresses. The whole discourse affirms that one should not fear authorities. Actually, Epictetus even takes fearless Christians an example of that (Disc. 4.7.6). ${ }^{77}$ They were surely not following what Paul states: "Do you wish to have no fear of the authority? Then do what is good, and you will receive its approval" (Rom 13:3). Paul unambiguously identifies obedience with what is good; accordingly, disobedience

\footnotetext{
$74 \quad$ Long 2002, 198.

75 See, e.g., Starr 1949.

76 Huttunen 2oo9, 87-88.

77 On Epictetus' sayings of Christians, see Chapter 2.
} 
toward the authorities is the same as distancing oneself from the good and living in fear. Yet, this was not the art of Epictetus and many other Stoics. Epictetus' resistance was in line with that of the so-called Stoic opposition embodied by Helvidius Priscus, who was martyred by Vespasian. ${ }^{78}$ Epictetus presents Helvidius' bold dialogue with the emperor as an example for future generations (Epictetus, Disc. 1.2.19-24). Helvidius and his father-in-law Thrasea Paetus, who was executed by Nero, became symbols for the philosophical and republican resistance in the early Empire. Even their memory was felt as a threat for the Empire, as Tacitus reports:

It is recorded that when Rusticus Arulenus extolled Thrasea Paetus, when Herennius Senecio extolled Helvidius Priscus, their praise became a capital offence, so that persecution fell not merely on the authors themselves but also on their books: the police, in fact, were given the task of burning in the courtyard of the Forum the memorials of our noblest characters.

Tacitus, Agr. 2; trans. HUTTON and PETERSON, LCL

Without blaming Thrasea or Helvidius for their resistance, Tacitus presents an alternative way for Agricola, his own father-of-law: "He read aright the reign of Nero, wherein to be passive was to be wise" (Agr. 6; trans. Hutton and Peterson, LCL). The Stoic Seneca seems to follow along the lines of Agricola, although he did not escape death but committed suicide, per Nero's order. Seneca differentiates between three types of fear, of which the third is the most fearful: "we fear (timentur) the troubles which result from the violence of the stronger" (per vim potentioris) (Ep. 14.3; trans. Gummere, LCL). It becomes clear that the stronger ones are the authorities, who make a parade with several violent acts.

Surrounding it is a retinue of swords and fire and chains and a mob of beasts to be let loose upon the disemboweled entrails of men. Picture to yourself under this head the prison, the cross, the rack, the hook, and the stake which they drive straight through a man until it protrudes from his throat. Think of human limbs torn apart by chariots driven in opposite directions, of the terrible shirt smeared and interwoven with inflammable materials, and of all the other contrivances devised by cruelty, in addition to those which I have mentioned! It is not surprising, then, if our greatest terror (timor) is of such a fate; for it comes in many shapes and its paraphernalia are terrifying (terribilis).

Seneca, Ep. 14.5-6; trans. GUMMERE, LCL 
Keeping Paul in mind, it is worth noting that Seneca assumes fear to be an important issue in the relationship between subjects and authorities. This relates to a more general belief in the connection between power and fear. Shepherd of Hermas seems to reveal that ancient ethos:

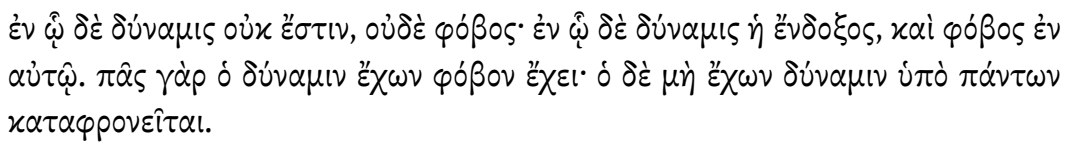

But in whom there is no power, neither is there fear. But in whom there is glorious power, there is also fear. For everyone who has power is feared; but the one who is powerless is despised by all.

Herm. Mand. 7.2 [37.2]; trans. EHRMAN, LCL

The passage presents as a piece of general wisdom the idea of power operating through fear. As shown above, this logic was also seen in the relationship to the state authorities: fear and power were interwoven, although some Stoics (like Epictetus) tried to disentangle them. Paul, in turn, accepted the connection between fear and power as an axiom. In Romans, one can see only the practical outcome of this conviction: Paul admonishes his audience to obey the

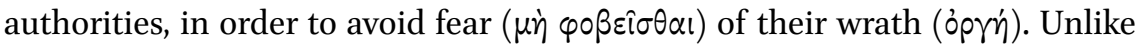
many other Stoics, Seneca is in line with Paul. He admonishes his readers to avoid anger: "So the wise man will never provoke the anger (potentium iras provocabit) of those in power; nay, he will even turn his course, precisely as he would turn from a storm if he were steering a ship" (Ep. 14.7-8; trans. Gummere, LCL). Similarly, Josephus has King Agrippa advise the following: "The authori-

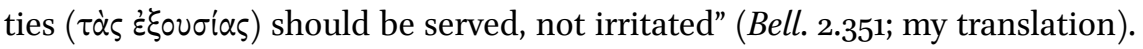
Again, this sounds quite similar to Paul. Such logic leads Seneca to recommend a quiet life outside the political sphere:

I beg you to consider those Stoics who, shut out from public life, have withdrawn into privacy for the purpose of improving men's existence and framing laws for the human race without incurring the displeasure of those in power (potentioris). The wise man will not upset the customs of the people, nor will he invite the attention of the populace by any novel ways of living.

Seneca, Ep. 14.14; trans. GUMMERE, LCL

Seneca's stance comes close to Epicurus' famous maxim "Live unknown" (Plutarch, Mor. 1128C). This is probably not a surprise, as Seneca repeatedly 
cites Epicurus in his Epistles. Epicurus' own relationship toward society is as similarly quietist as Seneca's in Ep. 14. In his Principal Doctrines 34-35, Epicurus' motivation for quietism is a life without fear:

Injustice is not in itself an evil, but only in its consequence, viz. the terror $(\varphi o ́ \omega)$ which is excited by apprehension that those appointed to punish such offences will discover the injustice. It is impossible for the man who secretly violates any article of the social compact to feel confident that he will remain undiscovered, even if he has already escaped ten thousand times; for right on to the end of his life he is never sure he will not be detected.

Diogenes Laërtius 10.151; trans. HICKS, LCL

Lucretius repeats these doctrines: a criminal can live undetected, but he can never be sure that his crimes will remain hidden: "Hence comes fear (metus) of punishment that taints the prizes of life" (Lucretius 5.1151-116o; trans. Rouse, LCL). Lucretius even ridicules how a fool not only fears the punishments in this life but also in the hereafter.

But in this life there is fear of punishment (metus in vita poenarum) for evil deeds, fear as notorious as the deeds are notorious, and atonement for crime-prison, and the horrible casting down from the Rock, stripes, executioners, condemned cell, pitch, red-hot plates, firebrands; and even if these are absent, yet the guilty conscience (mens sibi conscia factis), terrified before anything (praemetuens) can come to pass, applies the goad and scorches itself with whips, and meanwhile does not see where can be the end to its miseries or the final limit to its punishment, and fears (metuit) that these same afflictions may become heavier after death. The fool's life at length becomes a hell on earth.

Lucretius 3.1014-1023; trans. ROUSE, LCL

Epicurus and Lucretius put forth ideas that come quite close to what Paul presents in Romans 13. Both the Epicureans and Paul subscribe to the idea that one has to follow rules in order to avoid fear of punishment. Paul even seems to have noted the same thing as the Epicureans, namely, that authorities do not catch every wrongdoer. Paul asks and then answers, "Do you wish to have no fear of the authority? Then do what is good" (Rom. 13:3). He does not say that wrongdoers will be caught but only that they will live in fear. However, Paul takes seriously what Lucretius ridicules, that is, judgement in the hereafter: "those who resist will incur judgement" ( $x$ pi $\mu \alpha \lambda \eta^{\prime} \mu \psi \circ v \tau \alpha$; Rom. 13:2). The 
expression $x p i \mu \alpha \lambda \eta \dot{\eta} \mu \psi \circ v \tau \alpha \mathrm{l}$ is a hapax legomenon in Paul, but in the rest of the New Testament it refers to the Last Judgement (Matt. 23:14; Mark 12:40; Luke 20:47; Jas 3:1). ${ }^{79}$ Thus, Paul is aligned with Epicurus and Lucretius by claiming that criminals will always live in fear of punishment, but he differs from them by taking seriously the idea of divine punishment. There is also another aspect where Paul differs from the Epicureans. Epicurus claimed, "There never was an absolute justice, but only an agreement made in reciprocal intercourse" (Diogenes Laërtius 10.15o; trans. Hicks, LCL). In other words, justice and injustice are just human agreements. Therefore, the concrete content of justice differs according to time and place, as Epicurus states in the same context. There is no reason to think that 'good' and 'wrong' imply some totally different moral code in Romans 13:3-4 and its context, where Paul at least partly speaks of intra-Christian relationships (Rom 12:9, 17, 21; 13:10). Thus, the good required in intra-Christian relationships is the same good as that required by the authorities. ${ }^{80}$

In sum, Paul seems to differ from the Stoic opposition embodied by Helvidius Priscus and celebrated by, for example, Epictetus. Paul's answer to the law of the stronger is more quietist, being closer to Seneca's Epistle 14 and the Epicureans. I generally agree with Runar Thorsteinsson's conclusion that for Paul it was "important that the Christ-believers in Rome avoid unnecessary attention to themselves on behalf of the civic authorities." In Paul's words: "So far as it depends on you, live peaceably with all" (Rom 12:18)..$^{81}$ There is, however, one important difference between Paul and other quietists trying to cope with authorities. Paul assumed that the authorities really promoted the good and "therefore one must be subject, not only because of wrath but also because of conscience" (Rom 13:5). Why did Paul view the authorities so optimistically? The answer lies in the fact that the ancient ethics of the stronger were not without obligations for the good of the weaker. This has not won enough attention, because many modern readers tend to sympathize with a Bakunin-like disgust of hierarchy and power as such. This tendency blinds one to the positive aspect that many ancient people found in social hierarchies.

Plato's picture of Callicles and Thrasymachus cited above point out that the stronger make a profit from the weaker. Similarly, Paul admonishes his readers to pay taxes and revenues to the authorities (Rom 13:7), but he also points out an important difference in these Platonic figures. Paul does not present relative morals, which qualify the profit of the stronger as the good. He does

79 Huttunen 2009, 95.

$80 \quad$ Huttunen 2009, 97.

81 Thorsteinsson 2010, 99. 
not seek to justify the law of the stronger. In contrast, he optimistically claims that authorities operate "for your good" (Rom 13:4). The good the authorities promote is the good he also recommends to Christian in-group relations (Rom 12:9-10;13:8). There is no indication that the civil good would differ from the good of the Christian in-group. ${ }^{82}$ Thus, Paul claims that the authoritative power promotes justice in a genuine sense. This is quite an amazing claim. How could he think this? Is Paul proposing "a utopian vision of the state"? 83 Or is there any other explanation? Yes, there is.

I take an example of the ethics binding the stronger. Thucydides' report on the Athenians' shameless invocation of the law of the stronger in the Melian dialogue and the subsequent destruction of the city of Melos is often presented as a classical example of immoral power politics. ${ }^{84}$ This is a misconception, however. As I observed above, in ancient culture the stronger also had obligations toward the inferior. In the initial part of the dialogue, the Athenians openly state that they would like to have dominion over Melos "without trouble," that is, without destroying the city. However, they claim that the capitulation of Melos would save the city, "to the advantage of both." When the Melians ask what the advantage might be, the Athenians answer, "It would be to your advantage to submit before suffering the most horrible fate, and we should gain by not destroying you" (Thucydides 5.93; trans. Smith, LCL). This is surely a piece of war propaganda, but not altogether. The Athenians destroy Melos only as a fear-inspiring example to the other inferior cities in the Athenian dominion (Thucydides 5.99) how rebels are handled. As a general procedure, the destruction of inferiors would disadvantage the Athenians themselves. The dominion needed its subjects. ${ }^{85}$ At the end of the dialogue, the Athenians counsel the Melians "to acknowledge yourselves inferior to the most powerful state when it offers you moderate terms." The Athenians validate their counsel with a general wisdom: "Those who, while refusing to submit to their equals, yet comport themselves wisely towards their superiors and are moderate towards their inferiors - these, we say, are most likely to prosper" (Thucydides 5.111; trans. Smith, LCL). The exercise of power lies not in destroying but in moderate subjugation.

This wisdom is the moral code of the hierarchically structured ancient societies. One can find it also in Roman times. Lucretius ascribes it to the dawn

\footnotetext{
82 Wilckens 1982, 31; Huttunen 2009, 97-98. Thorsteinsson (2010, 98-99) makes the same point, but warrants that "it is hard to believe" that this would literally mean unlimited acceptance of the authorities.

83 Harrington and Keenan 2010, 170.

84 See, e.g., Crane 1998, 23 n3.

85 Crane 1998, 291-293.
} 
of the world, when the human race started to make covenants, "signifying by voice and gesture with stammering tongue that it was right for all to pity the weak" (Lucretius 5.1022-1023; trans. Rouse, LCL). Augustus boasts, "[A]s victor I was merciful to all citizens who asked for pardon. As for foreign peoples, those whom I could safely pardon, I preferred to preserve than to destroy" (Res Gestae 3; trans. Cooley). Virgil puts this thought into his verses: "Roman, be sure to rule the world (be these your arts), to crown peace with justice, to spare the vanquished and to crush the proud" (parcere subiectis et debellare superbos) (Virgil, Aen. 6.853; trans. Fairclough, LCL.). Josephus clearly recalls this morality after he has impressed the law of the stronger on besieged Jerusalem. He recounts what he told about the Romans to the Jews in the city:

The Romans would bear them no malice for the past, unless they persisted in their contumacy to the end: they were naturally lenient in victory, and would put above vindictiveness considerations of expediency, which did not consist in having on their hands either a depopulated city or a devastated country. That was why, even at this late hour, Caesar desired to grant them terms; whereas, if he took the city by storm, he would not spare a man of them, especially after the rejection of offers made to them when in extremities.

Josephus, Bell. 5.372-373; trans. Thackeray, LCL

This is a close variant of the story of Melos in The History of the Peloponnesian War. Both cities are advised to capitulate, such that the stronger would have the advantage of a living city, but both cities are destroyed after refusing subjugation. In a way, this morality is also found in Thrasymachus' crude words about rulers as shepherds who consider the good of the sheep in order to profit from the animals. The stronger takes care of the weaker for its own advantage. This is also the moral code which Teresa Morgan has detected in the popular morality of the early Roman Empire. Using as sources both fables and stories of exemplary figures, which predominantly deal with relations between the weak and the strong, she finds that hierarchy was seen as a natural phenomenon. The weak get advice to not put themselves in the way of the powerful, but instead try to show themselves as useful for the strong. Respectively, the strong should not destroy themselves by unwise treatment of their inferiors. ${ }^{86}$ The whole society is interconnected: everyone is bound to those above and below, and the exemplary figures Morgan discusses are loyal toward persons of higher rank. State institutions such as the army, censors, magistrates and law courts 
are regarded as moral authorities. ${ }^{87}$ Morgan shows that popular morality was connected with philosophy, ${ }^{88}$ as I presented above. Romans 13 is nothing but a Christian variation of this popular morality. Paul views the authorities optimistically, because they need their obedient subjects.

\subsection{The Imagination Made Real}

I showed that Romans 13:1-7 is a Christianized version of common ancient ethics. Its starting point is the prevailing social hierarchy, including its violent basis. It also seems to be ruthlessly realistic in the sense that it discouraged all attempts to change the society. However, this is not all. As Ranke clearly saw, Paul's teaching on authorities was a reaction to the social dynamite at the heart of the Christian beliefs which Paul himself shared. Paul was deeply convinced that the power structures were disappearing. His teaching on the authorities very smoothly transitions to that of Christian in-group ethics. After admonishing readers to give to the civil authorities what is due to them, he continues by advising Christians to owe nothing but mutual love. It is as if all other obligations could be fulfilled, but never the duty of love. The impending eschaton sharpens the ethical requirements. Troels Engberg-Pedersen has proposed that Paul is here depending on his Stoic ethics in 1 Cor. 7:31: those who deal with the world should deal "as if they had no dealings with it. For the present form of this world is passing away" (trans. slightly revised). According to Engberg-Pedersen, Paul similarly thinks here that the obligations to the authorities are secondary when compared to love:

Pay your taxes (fulfil your duties in that field) as something that can in fact be fulfilled. And then forget about it since the duty has, by now been fulfilled. In other words, do it "as if not". Or: do it, but without paying any special attention to it. That is not what matters. By contrast, fulfil your obligation to love. Or rather: try to fulfil it, always, and everywhere. For that is what matters. And that kind of life precisely belongs with the eschaton. ${ }^{89}$

87 Morgan 2007, 136, 142. There were alternative discourses, as Kartzow has shown, for example, in his study on the Pastoral Epistles. Kartzow (2009, 207) notes that the author of the Epistles rebukes women for gossiping, because "gossips" represent an alternative discourse. In this way women achieved power and influence. This single example shows that the hierarchical structure of society is not the whole truth of power in ancient society.

88 Morgan 2007, 274-299.

89 Engberg-Pedersen 2006, 170-171. 
The distinction between what matters and what does not matter is basic Stoic ethics, and 1 Corinthians 7 fits well into such a context. ${ }^{90}$ Even the idea of an impending eschaton is not strange in the Greco-Roman world. Lucretius reconstructs a theory of the growth and the fading of the world. He concludes, "now indeed the power of life is broken," and the world goes "to the reef of destruction" (Lucretius 2.1150, 1173-1174; trans. Rouse, LCL) ${ }^{91}$ Stoics represented the cyclic view of the universe: everything will be destroyed in a conflagration and/or deluge so that a new cycle can begin. In his Naturales quaestiones, Seneca says that the destruction will be sudden, and "a single day will bury the human race" (Nat. 3.27.2, 3.29.9; trans. Corcoran, LCL). According to Seneca, the deluge and the conflagration "will occur when it seems best to god for the old things to be ended and better things to begin." He estimates, "There will be no long delay in the destruction" (Nat. 3.28.7, 3.30.5; trans. Corcoran, LCL). ${ }^{92}$ Paul's vision is similar: "The night is far gone, the day is near" (Rom 13:12). The imminent end of this era emphasizes the right style of life (Rom 13:12-14), while Seneca emphasizes the vanity of all human achievements in the face of such cataclysms. ${ }^{93}$ For Paul, eschatology was a call for new values and new life; accordingly, he did not resist the state of the world being left behind.

Paul illustrates the requirement of a new life with the metaphor of "putting on the Lord Jesus Christ" (Rom 13:14). This is a clear reference to baptism. ${ }^{94}$ Robert Wilson estimates how baptism by immersion lent itself to the development of an imagery of "garment symbolism": "the candidate left his garments behind as he entered the water, and put on a fresh set of clothing when he emerged."95 By means of this new "garment," one should already imitate the coming world after the eschatological turn. This becomes clear in Romans 6, where Paul rebukes Christians for sinning. In baptism, Christians have mystically died to sin with Christ. This leads to the ethical conclusion: "For if we have been united with him in a death like his, we will certainly be united with him in a resurrection like his" (Rom. 6:5). Here is the future resurrection life projected onto the present as an ethical standard. ${ }^{96}$

As usual, the initiation revealed the central beliefs of the cult. What is of interest now in this chapter is the social dimension of the new faith. In the

$90 \quad$ See Chapter 2.

91 Interestingly, in 5.330-331 Lucretius claims just the opposite: "But, as I think, the world is young and new, and it is not long since its beginning."

92 See Heinonen 1990, 53-58; Downing 1995, 196-211.

93 Heinonen 1990, 57-58.

94 Jewett 2007, 827-828.

95 Wilson 2005, 25 .

96 Huttunen 2009, 148-149. 
Epistle of Galatians, Paul declares: "As many of you as were baptized into Christ have clothed yourselves with Christ. There is no longer Jew or Greek, there is no longer slave or free, there is no longer male and female; for all of you are one in Christ Jesus" (Gal 3:27-28). This maxim was seemingly a fixed part of the baptismal paraenesis. When it appears otherwise in the New Testament, it is always combined with baptism ( 1 Cor 12:13; Col $3: 11) .{ }^{97}$ One can easily see that the indifference to ethnic status lies at the heart of Paul's thinking, as he makes room for non-Jews among the Christians, but the baptismal paraenesis actually reveals that such indifference applies to other statuses within the baptized group as well. Male and female, slave and free are just examples of statuses which do not make any difference in the future life.

As the baptismal paraenesis shows, one of the cornerstones of this ethical standard is the lack of ethnic, status, gender, or-I suppose-any other characteristics. Of course, this does not mean that these characteristics somehow disappear, but that they are just adiaphora. In this tendency, Paul comes close to the ethics of the Stoics, where the world is organized by the divine logos. According to the Stoics, even the social structure of the world is divinely instituted, and every person occupies a social position at God's command. The social position itself does not matter. What counts is to fulfill one's duties as an official or slave or in any other position that one happens to find oneself occupying. Every person is equal to others and the different ranks are just like roles composed by the divine playwright. Therefore, a Stoic slave-owner is not obliged to set his or her slaves free, but to treat them humanely:98 "Do you not remember what you are, and over whom you rule-that they are your kinsmen, that they are your brothers by nature?" (Epictetus, Disc. 1.13.4; trans. Oldfather, LCL, revised).

The analogy between the Stoic and the Pauline thinking is clear: social differences are adiaphora, but in actual life they are not rejected. Interestingly, Paul admonishes everyone to remain in the social position he or she occupies. Not even slaves should try to find their freedom (1 Cor 7:17-24). The analogies with Stoic ideas (and even technicalities) are so distinct in these verses that I have referred to them as a Christian version of Stoicism. ${ }^{99}$ As an inner

\footnotetext{
97 Col 3:11 lacks a concrete reference to baptism, but the symbol of "clothing" in 3:9-10 is clearly a reference to baptism (Wilson 2005, 250).

98 Huttunen 2009, 24-26, 45. On the Stoic idea of equality, especially between genders, see Grahn's profound study (2013).

99 See Chapter 2. Paul's words on slaves can also be understood in the way that slaves should promote their emancipation when possible. If so, the parallel with Stoicism may be even clearer (Bonhöffer 1911, 171). However, I have philologically argued against the interpretation that Paul would admonish the promotion of emancipation (Huttunen 2009, 28-29).
} 
conviction, Paul's Christianity makes no less an impact than does Stoicism. Paul's short epistle to a certain Philemon stands as witness to this. The theme of this epistle is the slave Onesimus, who was probably a runaway. Paul returns Onesimus to his owner "no longer as a slave but as more than a slave, a beloved brother" (Philem. 16). The short personal letter should not be read as an overall statement on slavery or even on the treatment of runaways, ${ }^{100}$ but the human tone is distinctive and fits well with the baptismal paraenesis.

Among the statuses that become irrelevant through baptism are those of the stronger and the weaker. This is highly interesting after noting the law of the stronger in Paul's teaching on civil authorities in Romans 13:1-7. Paul takes up the relationship between the strong (oi $\delta v v \alpha \tau o i)$ and the weak ( $\dot{\delta} \alpha \sigma \theta \varepsilon v \hat{\omega} v$, oi $\left.\alpha \delta 0 v \alpha \tau 0^{i}\right)$ in the next chapters. In this case it is a question of weakness and strength in spiritual matters: the weak are scared by the "idol food," while the strong-among whom Paul counts himself-know that "nothing is unclean in itself" (Rom 14:14). This spiritual strength is parallel to the moral strength shown by the physically conquered person in Epictetus' example (see above). It is characteristic of an ancient mind that people are classified by their strength, even in intellectual, moral, and spiritual matters. Disputes between the strong and the weak are the subject of Paul's pastoral guidance in Romans 14-15. He presents himself as though he were a sage from the Golden Age. Posidonius (cited by Seneca) says that in the Golden Age, "the government was under the jurisdiction of the wise. They kept their hands under control, and protected the weaker from the stronger (infirmiorem a validioribus)" (Seneca, Ep. 90.5; trans. Gummere, LCL).

Paul tries to smooth over the disagreements between the strong and the weak, although he identifies himself with the strong (Rom. 15:1) and gives philosophical arguments for their views. ${ }^{101}$ Moreover, the apostle does not even try to get rid of the traditional vocabulary of the weak and the strong. He classifies believers as weak or strong in matters of faith. In this sense, he also accepts a social hierarchy within the Christian in-group. It is secondary, however, as both subgroups share the common interest of giving glory to God: "Those who eat, eat in honour of the Lord, since they give thanks to God; while those who abstain, abstain in honour of the Lord and give thanks to God" (Rom 14:6). They should thus recognize each other's practices as differing outcomes of the same conviction. This illustrates the fact that though "the night is far gone," there are still Jews and Greeks, slaves and freedmen, males and females-and also strong and weak. The dawn has not yet broken, and one can only get a dim idea

100 See the discussion by Glancy (2002, 91-92).

101 Huttunen 2009, 71-74. 
(cf. 1 Cor. 13:12) of the future non-hierarchies. Paul ridicules the Corinthians who, according to him, already claim to have reached the eschatological fullness: "Already you have become rich! Quite apart from us you have become kings! Indeed, I wish that you had become kings, so that we might be kings with you!" (1 Cor. 4:8). This ideal, which Paul ascribes to the Corinthians, is a Stoic one. Diogenes Laërtius relates that Zeno and Chrysippus taught about the kingship of the wise.

According to them not only are the wise free, they are also kings; kingship being irresponsible rule, which none but the wise can maintain: so Chrysippus in his treatise vindicating Zeno's use of terminology. For he holds that knowledge of good and evil is a necessary attribute of the ruler ( bad man is acquainted with this science. Similarly the wise and good

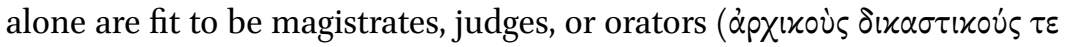

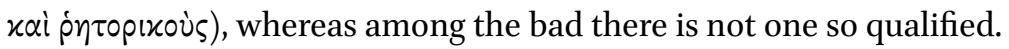

Diogenes Laërtius 7.122; trans. HICKS, LCL

According to Paul, it is premature to claim that someone has already become a philosopher-king. Even Stoics would deny those claims, except in the case of few uncommon figures. For Epictetus, such figures were only Diogenes of Sinope, Socrates, or Heracles. ${ }^{102}$ For Paul, the Corinthian claim is also premature, because the eschatological kingdom has not yet come. Besides this prematureness, Paul sees nothing wrong with the Stoic ideal, which is nothing but anarchical. In the future commonwealth (Phil. 3:20), there are only the saved, all of whom are wise. They all become kings, who hold knowledge of good and evil, the same knowledge and power authorities have in this world (Rom. 13:3-4). Therefore, the need for hierarchies will disappear. Actually, this is what Paul expects of Christ when that new day dawns: "He hands over the kingdom to God the Father, after he has annulled every ruler and every author-

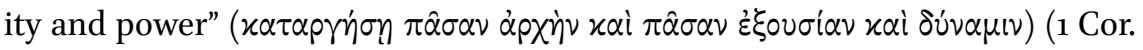
15:24; trans. revised). ${ }^{103}$ This is anarchy, but not in the sense of armed revolution or any other practical resistance. The opposition toward earthly empires is just on the ideological level, whereas on the social level Paul pursued peace with all (Rom 12:18). ${ }^{104}$

\footnotetext{
102 Downing 1998, 88-9o; Huttunen 2009, 130-139.

103 Paul can also mean celestial angelic or demonic powers, or there can be a double meaning in these verses. See Schrage 2001, 173-174.

104 Klostergaard Petersen 2015, 123.
} 
However, Paul also expected something to happen on the concrete level. With a reference to Romans 14, French philosopher Alain Badiou claims: "Paul takes great pains to explain that what one eats, the behavior of a servant, astrological hypotheses, and finally the fact of being Jewish, Greek, or anything else-all this can and must be envisaged as simultaneously extrinsic to the trajectory of truth and compatible with it."105 This is certainly true in Romans 14, but this is an overstatement if it is presented as Paul's overall conviction, as Badiou does. Badiou wants to show that Paul was not promoting anti-Judaism or misogyny, but rather a genuine universalism that transcended all differences. ${ }^{106}$ To just take the case of the Jews, one can read a lengthy discussion on them in Romans 9-11. It proves that Paul indeed had a serious intention to find a place for non-Christian Jews within salvation, but he fluctuated between different solutions and ended up leaving the matter to God. ${ }^{107}$ Ultimately, he could not find a universal solution. However, his intention toward one was undeniable. His intention was to eliminate any hierarchical differences.

The limitation of Paul's universalism is clearly revealed when his thoughts are compared with those of the Stoics. Runar Thorsteinsson claims that "Roman Christianity and Roman Stoicism are fundamentally similar in terms of morality or ethics," but that only Stoics taught universal humanity. The Christian texts, in turn, "reserve the application of their primary virtue for fellow believers." ${ }^{108}$ This is easily seen, for example, in Romans 13:8-10: here Paul exhorts the Christians to mutual love. While he surely does not leave nonChristians out, or say they are not worthy of concern, the main line highlights in-group matters. ${ }^{109}$ This is due to the fact that the equality of all people is closely tied to faith and baptism in Christ. Transcending differences-say, between slaves and freedmen-is closely reminiscent to what the Stoics said. But whereas equality for the Stoics was based on common humanity, here it was based on Christ. This is clearly visible in 1 Corinthians 7:17-24. ${ }^{110}$ Nevertheless,

\footnotetext{
105 Badiou 2003, 100.

106 Badiou 2003, 101-116. It is revealing that Badiou claims that Paul did not accuse the Jews of deicide. This is true, but deceiving. Although Paul does not speak of deicide, he ruthlessly blames Jews for being enemies of humankind and for murdering Christ ( 1 Thess 2:15). This is so heightened a claim that one is tempted to see it as an interpolation. There is, however, no manuscript evidence for this proposition. In the case of women, Badiou is more sensitive. He admits that Paul sometimes utters things that are unacceptable today. However, "the only question worth asking is whether Paul, given the conditions of his time, is a progressive or a reactionary" (Badiou 2003, 104-116).

107 For an illustrative discussion on Rom 9-11, see Räisänen 2008.

108 Thorsteinsson 2010, 209. See also Engberg-Pedersen 2013.

109 Huttunen 2009, 71; Thorsteinsson 2010, 193-194.

110 See Chapter 2.
} 
there was really a universal mission in early Christianity: to make disciples of all nations ( $\left(\varepsilon^{\prime} \theta \eta\right)$ (Matt 28:19). This was also Paul's mission in the sense that he believed himself to be "the apostle to the nations ( $\dot{\theta} \theta \omega \hat{\omega} \nu \alpha \dot{\alpha} \dot{\sigma} \sigma \tau 0 \lambda \circ \varsigma)$ " (Rom 11:13; trans. revised). That there is no independent, humanistic interest toward outsiders is a completely understandable situation in a cult that projected all good onto Christ. In short, there was no freedom, equality, or brotherhood outside of Christ.

For some people, such a Christian outlook is regarded as too restrictive and vague, or even an illusion. They rationalized that because "there is so much hellish," people take refuge in religion, "the creation of a world of fantasy."111 Instead of fantasy they would rather that such goals be realized in and for the whole of society. The Russian Revolution and subsequent communist revolutions around the world were attempts at consummating the eschatological imagination. The Marxist philosophy of history can be seen in this light as a secular variant of Jewish-Christian apocalypticism: ${ }^{112}$ according to this view, global revolution will be the final conflict, Armageddon. Amid the battle, a devout revolutionary could have the premonition "that this will be the last one,"113 to be followed by everlasting human unity. Although apocalyptic Marxism has its prehistory from the late 16 th century on, ${ }^{114}$ the Marxist union of the secular and the sacred is probably the strongest revolutionary power ever seen in history. ${ }^{115}$ Lenin put into practice the revolutionary spirit that he saw in the original Christianity, here apparently being under the influence of Friedrich Engels, who took the Book of Revelation as the original expression of Christianity. ${ }^{116}$

After few years after the Russian Revolution, enthusiasts claimed that the teachings of Jesus were "being realized in Russia." But the disillusioned anarchist Emma Goldman was less keen in her comments: "A preposterous falsehood."117 Indeed, what actually followed the October Revolution of 1917 was a realization of the bloody visions of John the Seer. The picture of blood rising to the bridles of horses (Rev 14:20) was not far away. The Black

\footnotetext{
111 Dzerzhinsky 1959, 221 (March 9, 1914).

112 See, e.g., Zimdars-Schwartz and Zimdars-Schwartz 1998, 286-289; Baumgartner 1999, 201-2O2.

113 Dzerzhinsky 1959, 291 (August 22, 1918). Dzerhinsky's prison diary and letters document his constant faith in a kind of eschatological reality in the secular Marxist form. Lauchlan (2015, 101-104) also notes Dzerzhinsky's Christian-like sentiment.

114 Räisänen 2017, 199. On the prehistory, see Funkenstein 1986, 202-289.

115 Altizer 1998, 341.

116 Engels 1894-1895.

117 Goldman 1924, 96-97.
} 
Book of Communism counted nearly 100 million deaths on the communist conscience. ${ }^{118}$ The exact number of victims is debated, but no one questions that the number was huge. The modern Bolshevist apocalypticists, however, saw spilling of blood with pleasure. For Lenin (citing Engels), revolutionary violence was good power in contrast to the "diabolical power" of the old society.119 Along these lines, Lenin's servants in the Cheka, the political police, were instructed to crush the old world in the apocalyptic turn toward the new eon:

Our morality is new, our humanity is absolute, for it rests on the bright ideal of destroying all oppression and coercion. To us all is permitted, for we are the first in the world to raise the sword not in the name of enslaving and oppressing anyone, but in the name of freeing all from bondage.... Blood? Let there be blood ... for only the complete and final death of that [old] world will save us from the return of the old jackals. ${ }^{120}$

Felix Dzerzhinsky, the founder and the first leader of Cheka, was at pains to explain to his sister why "there is no name more terrifying than mine," while "love is everything for me." He claimed to "banish injustice from the world."121 "My purpose compels me to be merciless," he relates to his wife. ${ }^{122}$ This is how the Marxist eschatology took form in one individual who had spent years in the prison of the previous authorities. Violent rule was dethroned by even more intense violent rule. Is this exactly what happens in the Book of Revelation? The Lamb of Revelation begins to look here like a dragon or the Beast of the same book. The Lamb, who was earlier a slaughtered victim, destroys his enemies after all (Rev 19), just like the Beast who waged war against the followers of the Lamb (Rev 13:7). This is how David L. Barr puts the moral problem of the last book in the Bible. ${ }^{123}$ The Lamb becomes the new power. In a sense, John's vision foreshadows the Christian empires, which eagerly utilized Paul's legitimation for their dominance. Not even Lenin's rule forgot such a useful biblical passage. Pyotr Krasikov, the deputy of the People's Commissar of Justice, claimed in 1919 that Romans 13 belongs among the most important sayings of the apostle. Krasikov deplored that Tikhon, the Patriarch

\footnotetext{
118 Courtois et al. 1999 .

119 Lenin 1974, 404.

120 These words are from 1919 and the first issue of The Red Sword, a weekly periodical of the Ukrainian Cheka. Cited and translated by Leggett 1981, 203 (my clarification in brackets is based on the textual context).

121 Dzerzhinsky 1959, 293-294 (April 15, 1919).

122 Dzerzhinsky 1959, 290 (May 27, 1918).

123 Barr 2006, 218. Barr himself takes distance from this reading while aptly describing it.
} 
of Moscow and All Russia, did not use it to elucidate the relationship between the state and the church. ${ }^{124}$ Once they seized power, the Bolsheviks claimed to reign as those before-despite the fact that this was not their stated aim. Lenin wrote:

We do not after all differ with the anarchists on the question of the abolition of the state as the aim. We maintain that, to achieve this aim, we must temporarily make use of the instruments, resources, and methods of state power against the exploiters, just as the temporary dictatorship of the oppressed class is necessary for the abolition of classes. ${ }^{125}$

The anarchists also preached social revolution. ${ }^{126}$ The temporary means that Lenin enumerated were just more longstanding than those held by the anarchists. Emma Goldman demanded that the means of revolution should be identical with the purposes to be achieved. In a weird way, she still suggested that violent revolution inspires "with a new concept of life and its manifestations in social relationships,"127 obviously expecting something else than the state and state-driven terror. While the anarchists believed in an immediate collapse of the state after revolution, Lenin ridiculed this idea by citing Engels:

Have these gentlemen ever seen a revolution? A revolution is certainly the most authoritarian thing there is; it is an act whereby one part of the population imposes its will upon the other part by means of rifles, bayonets and cannon, all of which are highly authoritarian means. And the victorious party must maintain its rule by means of the terror which its arms inspire in the reactionaries. ${ }^{128}$

The Marxists saw how contradictory the anarchists were when they promoted authoritarian methods to destroy the authorities. Oddly enough, the Marxists did not see a contradiction between their own lasting violence and the ultimate abolition of authority. As a consequence, the state was never abolished but strengthened rather. This is the lesson that history provides: the revolutionary heritage of the Christian tradition leads to disaster, turns the Lamb into

\footnotetext{
124 Rössler 1969, 116.

125 Lenin 1974, 441.

126 Bakunin $(1907,16)$ thought that the oppressive structures can be circumvented in three ways: "two chimerical and a third real. The first two are the dram-shop and the church, debauchery of the body or debauchery of the mind; the third is social revolution."

127 Goldman 1924, 175 .

128 Engels 1913, 39 (translation in Lenin 1974, 442-443).
} 
the Beast, and makes the victim a victimizer. Is there a non-revolutionary alternative? The strong emphasis on obedience to authority has certainly played its part in oppressive societies. One routinely refers to Auschwitz as a horrible outcome of honoring the powers that be. This is not the whole truth, however. Northern European countries with Romans 13:1-7 as their underlying political ethos have never become totalitarian states. Instead, they have been receptive to ideas of a state-driven welfare system. ${ }^{129}$

Paradoxically, preserving eschatology as a vision for the future has at least led to some general changes in the society as a whole. How did this happen? Christianity was just another little cult in Paul's time, and the apostle showed but a piece of realism when accepting the Empire as it was. What he could expect was a new order among those who found the source of all good. The eschatological imagination could be acted on, and so come true, insofar as this occurred in the attitudes of the Christian in-group. On the more general level, Paul could put trust only in Christ, who will destroy "every ruler and every authority and power" (1 Cor 15:24). While waiting for this divine revolution, it was better for Christians to realistically lead a quiet life in the Empire and "deal with the world as though they had no dealings with it. For the present form of this world is passing away" (1 Cor. 7:31). More important for Paul is the new order among those in Christ. This is how Jacob Taubes understood Pauland rightly so:130 "Paul's genius was to create of a parallel state that posed no immediate threat to the existing political structure, the Roman state."131 But the story did not end when Paul passed away. What he could not expect or even imagine is that such a vision would come true, also at the practical level of social structures, already before the form of this world passed away. At least in the case of slavery, Christian attitudes gradually influenced society. Clement of Alexandria, an early Christian theologian (ca. $200 \mathrm{CE}$ ), required a decrease in work by slaves. Although the theologians usually admitted slavery as a matter of fact, it became more and more restricted. In a sense, the anti-hierarchical spirit corrupted the system of slavery from the inside. Certainly, the development toward the end of slavery was not without some backtracking; in

129 Nelson 2017 , 104. Karimäki $(2019,52)$ aptly describes the mentality that resisted the right-wing takeover in the 1930s: "Finnish liberal anti-fascism and the policy of national unification were anti-communist, democratic, parliamentarian, legalistic and nationalistic in nature. This combination of liberal yet nationalistic values aspired to achieve a united nation in spirit and mentality, but never a coerced acceptance of a single political ideology."

130 Taubes 2004, 52-54.

131 Blumenfeld 2003, 389. Similarly, see Klostergaard Petersen 2015, 116. 
addition, the general prohibition of slavery was not only due to Christianity. ${ }^{132}$ However, Christianity did play a significant role in that process. ${ }^{133}$ In other words, what Marx rejected as a fantasy has had a more powerful effect than violent revolution.

Today, it is difficult to imagine any serious Christian leader who would share Paul's opinion that slaves should not pursue their freedom. At the level of the letter, these modern Christians have put aside "what the Bible says." There is no general prohibition of slavery in the Bible, and even Paul accepted it. However, Paul also says that "we are slaves not under the old written code but in the new life of the Spirit" (Rom. 7:6; cf. 2 Cor 3:6). He preached spiritual change, and therefore we can legitimately ask if the one who follows his spirit is more his disciple than the one who follows his letters. From this spiritual point of view, the limitations placed on Romans 13 can be justified, although they go against the letters that Paul wrote. Do such limitations not actually enhance Paul's vision that there will be an end of "every ruler and every authority and power" (1 Cor 15:24)?

132 That Paul's ideal of equality among Christians was easily changed back to the ethics of the law of the stronger is illustrated by Clement of Rome, who wrote only a few decades after

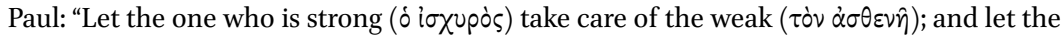
weak show due respect to the strong. Let the wealthy provide what is needed to the poor, and let the poor offer thanks to God, since he has given him someone to supply his need" (1. Clem. 38.2; trans. Ehrman, LCL).

133 Klein 200o; Turley 200o; Ramelli 2016. 